\title{
Meta-Analisis Efektivitas Model Problem Based Learning Terhadap Kemampuan Berpikir Kritis Dan Sikap Ilmiah
}

\author{
Syafiatuz Zahro ${ }^{1}$ ); Nanang Purwanto ${ }^{2}$ ) \\ 1) Mahasiswa Tadris Biologi, Fakultas Tarbiyah dan Ilmu Keguruan (FTIK), Institut Agama Islam \\ Negeri (IAIN) Tulungagung \\ $\left.{ }^{2}\right)$ Dosen Tadris Biologi, Fakultas Tarbiyah dan Ilmu Keguruan (FTIK), IAIN Tulungagung \\ Email korespondensi: sopiazara5738@gmail.com
}

\begin{abstract}
S
This study aims to determine the effectiveness of the Problem Based Learning (PBL) model on students' critical thinking skills and scientific attitudes based on education level, learning materials and teaching materials used. This research used meta-analysis method. This research was obtained from 7 national scientific journals. Based on the results obtained based on the level of education, the PBL model is effectively used at the junior high school and senior high school levels. Based on learning materials, PBL models are used to develop critical thinking skills and scientific attitudes. Based on the learning material, the PBL model is more effective in using the human respiratory system material for critical thinking skills and scientific attitudes. Then based on the teaching materials, all teaching materials are effective when using the PBL model for critical thinking skill and scientific attitudes.
\end{abstract}

Keywords: Meta-Analysis, Problem based Learning, Critical Thinking Skill, Scientific Attitudes.

\begin{abstract}
ABSTRAK
Penelitain ini bertujuan untuk mengetahui efektivitas dari penerapan model Problem Based Learning (PBL) terhadap kemampuan berpikir kritis dan sikap ilmiah siswa berdasarkan jenjang pendidikan, materi pembelajaran dan bahan ajar yang digunakan. Metode yang digunakan adalah meta-analisis. Penelitian ini diperoleh dari 7 jurnal ilmiah nasional. Berdasarkan hasil yang diperoleh berdasarkan jenjang pendidikan, model PBL efektif digunakan pada jenjang SMA maupun SMP. Berdasarkan materi pembelajaran, model PBL untuk mengembangkan kemampuan berpikir kritis dan sikap ilmiah. Berdasarkanmateri pembelajaran, model PBL lebih efektif menggunakan materi sistem pernapasan manusia untuk kemampuan berpikir kritis dan sikap ilmiah. Kemudian berdasarkan bahan ajar seluruh bahan ajar efektif jika menggunakan model PBL untuk berpikir kritis maupun sikap ilmiah.
\end{abstract}

Kata Kunci: Meta-analisis, Problem Based Learning, Kemampuan Berpikir Kritis, Sikap Ilmiah

\section{PENDAHULUAN}

Pendidikan memegang peranan penting dalam mempersiapkan sumber daya manusia yang berkualitas agar mampu bersaing dan berkompetisi dalam menghadapi perkembangan di masa mendatang, pendidikan juga bukan hanya sebagai wadah penyampaian informasi, ataupun interaksi antar pendidik dan peserta didik namun juga sebagai media atau tempat menuangkan ide, dan fasilitas bagi peserta didik mengasah kemampuan berpikir.

Dalam kurikulum terbaru pada jenjang Mata pelajaran Ilmu Pengetahuan Alam SMP/MTs menerapkan pembelajaran sains terpadu. Dan di tingkat SMA/MA Ilmu Pengetahuan Alam disajikan sebagai mata pelajaran yang spesifik yang terbagi dalam mata pelajaran Fisika, Kimia, dan Biologi. IPA merupakan suatu sistem untuk mengetahui tentang alam melalui pengumpulandata dari observasi dan eksperimen (Chiappetta \& Koballa, 2010). Selanjutnya dalam Ilmu pengetahuan Alam ataupun mata pelajaran Biologi, alam sebagai objek utama penelitian dikaji melalui tahap observasi, menyusun hipotesis, eksperimen sehingga menghasilkan data kemudian dianalisis hingga kemudian ditarik suatu kesimpulan sebagai pengetahuan dan dapat diaplikasikan dalam masyarakat. Dalam (Kemendikbud, 2013.) dijelaskan sebagai contoh implementasi pengembangan kurikulum Biologi SMA tidak terlepas dari trend masa depan dalam lingkup Biologi, terutama kebutuhan kehidupan dari penerapan Biologi dalam kehidupan sehari-hari. Terkait juga mengenai kurikulum yang saat ini diberlakukan yakni kurikulum 2013 yang didalamnya memuat tentang kompetensi sikap, pengetahuan, keterampilan dalam pembelajaran yang terpengaruh oleh lingkungan keluarga, sekolah, dan masyarakat. Teknologi yang didasarkan pada proses biologi menjadi salah satu ciri Abad 21 untuk menyelesaikan masalah kehidupan yang semakin rumit dan kompleks sehingga memerlukan solusi yang efektif dan efisien yang ramah lingkungan.

Peserta didik diharapkan tidak hanya sebatas mencapai tujuan pembelajaran mengetahui dan memahami, akan tetapi juga pada tahap menumbuhkan kebiasaan berpikir kritis dan sikap ilmiah . Kemampuan berpikir kritis adalah proses mental yang mencakup kemampuan merumuskan masalah, memberikan dan 
menganalisis argumen, melakukan observasi, menyusun hipotesis, melakukan deduksi dan induksi, mengevaluasi, dan mengambil keputusan serta melaksanakan tindakan (Nursiti \& Barat, 2013).

Sedangkan sikap ilmiah menurut (Muslich, 2008) merupakan sikap yang harus ada pada diri seorang ilmuwan atau akademisi ketika menghadapi persoalan-persoalan ilmiah. Sikap ilmiah yang cenderung dikembangkan di berbagai sekolah meliputi 1) Curiosity (sikap ingin tahu), 2) Fleksibility (sikap ilmiah), 3) Critical reflection (sikap kritis), 4) sikap jujur (Purwaningsih, 2007).

Kemampuan berpikir kritis serta sikap ilmiah ini hanya dapat dikuasai peserta didik jika guru dapat menciptakan lingkungan belajar yang tepat. Dan itu dipengaruhi juga oleh pemilihan metode pembelajaran yang mendukung bagi peserta didik mengembangkan kemampuan berpikir kritis dan sikap ilmiah. Meskipun faktanya dilapangankebanyakan peran peserta didik dalam proses pembelajaran cenderung pasif, terutama dalam mata pelajaran yang dicap sebagai mata pelajaran hafalan salah satunya adalah Biologi, ini disebabkan oleh masih diterapkannya metode konvesional yakni guru sebagai pusat pembelajaran, sehingga interaksi antara guru dengan peserta didik kurang efektif.

Salah satu model pembelajaran yang menurut para ahli efektif dalam mengembangkan keterampilan berpikir kritis serta sikap ilmiah ialah model Problem Based Learning (PBL) . Problem Based Learning sesuai untuk menciptakan lingkungan belajar yang baik. PBL mempersiapkan peserta didik berpikir kritis, analitis, dan menemukan dengan menggunakan berbagai macam sumber (Sumarmi, 2012). Begitupun juga untuk penanaman sikap ilmiah, peserta didik dihadapkan pada suatu permasalahan-permasalahan yang termasuk sintaks dari PBL yang nantinya digunakan sebagai pijakan dalam mempelajarai suatu hal guna mengasah dan mengembangkan sikap ilmiah. Model pembelajaran berbasis masalah akan melibatkan siswa secara aktif karena siswa dihadapkan pada masalah yang dihadapi oleh masyarakat, salah satunya seperti pencemaran lingkungan yang akan diselesaikan melalui metode ilmiah (Made W, 2009).

Kemudian (Arends, 2004) mengemukakan ada 5 fase (tahap) yang perlu dilakukan dalam menerapkan model pembelajaran PBL yakni meliputi 1) Mengorientasi siswa pada masalah, 2) Mengorganisasi siswa untuk belajar, 3) Membimbing penyelidikan individu dan kelompok, 4) mengembangkan dan menyajikan hasil karya, 5) Menganalisa dan mengevaluasi proses pemecahan masalah. Dari tahapan atau sintaks tersebut dapat ditarik kesimpulan bahwa dalam setiap proses pemebelajarannya akan lebih banyak melibatkan peran peserta didik dan kemudian memunculkan sikap ilmiah. Peserta didik yang menerapkan sikap ilmiah akan mampu memecahan masalah dalam kehidupan sehingga peserta didik dapat berpikir kritis serta inovatif.

Pada kurikulum terbaru dijelaskan juga bahwa guru bukan lagi sebagai satu-satunya sumber informasi didalam kelas, maka peran ini akan dibantu dengan adanya bahan ajar. Dengan adanya bahan ajar guru lebih berperan sebagai fasilitator untuk mengarahkan dan membimbing peserta didik dan bahan ajar juga membantu proses pembelajaran menjadi lebih efektif sehingga juga dapat menghemat waktu guru mengajar. Bahan ajar pun kini beragam jenisnya ada yang berupa bahan ajar cetak, contohnya seperti modul, LKS (Lembar Kerja Siswa), Handout, majalah. Selain itu terdapat juga media noncetak diantaranya terdapat audio, video dan bahan ajar besbasis computer. Semantara bagi siswa menggunakan bahan ajar juga siswa dapat melakukan proses belajar secara mandiri. Artinya siswa dapat memiliki kesempatan dimana dan kapan ia dapat belajar dengan metode belajar mereka sendiri. Bahan ajar sangat penting, artinya bagi guru maupun siswa dalam proses pembelajaran. Tanpa bahan ajar akan sulit bagi guru untuk meningkatkan efektivitas pembelajaran. (Setiawan, D. 2007).

Kendati demikian, tidak seluruhnya proses belajar-mengajar berjalan mulus, beberapa hambatan selalu muncul diluar rencana. Diantaranya yang kerap terjadi seperti contohnya ketidaktepatan penggunaan model dengan materi pembelajaran, ketidaksiapan siswa dalam menerima model tertentu, bahan ajar yang belum efektif diterapkan dalam metode dan materi tertentu. Hal inilah biasanya yang mengurangi keefektifan pembelajaran. Maka dari itu dalam pada penelitian ini akan dianalisis 6 jurnal ilmiah mengenai pembelajaran yang menggunakan model Problem Based Learning terhadap kemampuan berpikir kritis dan sikap ilmiah peserta didik ditinjau dari jenjang pendidikan, bahan ajar yang digunakan dan materi pembelajarannya. Peneliti menggunakan metode meta-analisis Dari penelitian ini diharapkan kepada para pengajar agar dapat memilih model,dan bahan ajar yang tepat dalam masing- masing jenjang pendidikan. Serta penelitian ini dapat bermanfaat bagi pengajar Biologi maupun IPA terpadu dikemudian hari.

\section{METODE PENELITIAN}

Penelitian ini menggunakan metode meta-analisis. Dalam metode meta-analisis dilakukan dengan cara mereview, merangkum, dan menganalisis data penelitian dari beberapa hasil penelitian. Tekhnik pengumpulan data yaknni dilakukan dengan menelusuri jurnal ilmiah pada beberapa media elektronik khususnya pada Google Cendekia. Instrumen penelitian ini dengan cara pengokodean, yang mana variable-variabel penelitiannya ialah: 1) berdasarkan jenjang pendidikan 2) berdasar materi pelajaran 3) berdasarkan bahan ajr yang digunakan.

Dalam penelitian ini digunakan 7 sampel jurnal ilmiah dan kemudian dibagi lagi menjadi dua kelompok yakni jurnal untuk meneliti keefektifan Problem Based Learning terhadap keterampilan sikap ilmiah, dan rinciannya dapat dilihat pada Tabel 1 yang terdiri dari 4 jurnal. Pada Tabel 2 meneliti tentang keefektifan Problem Based Learning terhadap kemampuan berpikir kritis yang terdiri dari 3 jurnal ilmiah. 
Tabel 1. Distribusi dari 4 Sampel Penelitian untuk Keterampilan Sikap Ilmiah

\begin{tabular}{llcc}
\hline Keterangan & Jenjang pendidikan & Materi & Bahan Ajar \\
& 1 & & \\
SMP & 3 & & \\
SMA & & 3 & \\
Sistem Pernapasan Manusia & 1 & 1 \\
Pencemaran Lingkungan & & & 1 \\
Media TIK & & & 2 \\
Modul & 4 & 4 & 4 \\
Non bahan & 4 & & \\
Jumlah & & & \\
\hline
\end{tabular}

Pada Tabel 1. Ini dijelaskan rincian sampel tentang model Problem Based Learning terhadap keterampilan sikap ilmiah peserta didik, terdiri dari 1 jurnal pada jenjang SMP/MTs dan 3 jurnal pada jenjang SMA/MA dengan materi sistem pernapsan manusia, air/lingkungan dan pencemaran lingkungan. Kemudiann bahan ajar yang digunakan adalah modul, 1 jurnal menggunakan media TIK dan 1 jurnal tidak menggunakan bahan ajar.

Tabel 2. Distribusi dari 4 Sampel Penelitian untuk Keterampilan Berpikir Kritis

\begin{tabular}{llcl}
\hline Keterangan & Jenjang pendidikan & Materi & Bahan Ajar \\
& & & \\
\hline SMP & 1 & & \\
SMA & 2 & 1 & \\
Sistem Pernapasan Manusia & & 1 & \\
Air dan Lingkungan & 1 & 1 \\
Psikotropika & & 1 \\
Komik & & & 1 \\
LKS & 3 & 3 & 3 \\
Non bahan & & & \\
Jumlah & & & \\
\hline
\end{tabular}

Pada Tabel 2. Membahas rincian dari 3 jurnal ilmiah yang meeliti tentang model Problem Based Learning terhadap kemampuan berpikir kritis, yang mana terdapat 3 jurnal ilmiah yakni 1 jurnal pada jenjang SMP/MTs dan 2 jurnal pada jenjang SMA/MA. Dengan 1 jurnal membahas tentang sistem pernafasan manusia, 1 jurnal tentang pencemaran lingkungan dan 1 jurnal tentang materi psikotropika. Mengenai bahan ajar 1 jurnal menggunakan media komik, 1 jurnal menggunakan LKS dan satu jurnal tidak menggunakan bahan ajar.

Penelitian ini menggunakan tekhnik analisis deskriptif dengan menganalisis jurnal ilmiah dan menelaah secara langsung pada jurnal tersebut, jika menghitung nilai gain berdasarkan hasil pretest dan posttest peserta didik. Cara menghitung skor Gain yang dinormalisasi berdasarkan rumus menurut (Archambault, 2008) yaitu:

$\mathrm{N}-$ Gain $=\frac{\text { Skor Posttest }- \text { Skor Pretest }}{\text { Skor Maks-Skor Pretest }} \times 100$

Hasil skor Gain dibagi dalam tiga kategori yaitu:

Tabel 3. Kriteria Nilai Gain

\begin{tabular}{ll}
\hline Presentase & Klasifikasi \\
\hline $\mathbf{N}$-gain $>\mathbf{0 , 7 0}$ & Tinggi \\
$\mathbf{0 , 3 0} \leq \mathbf{N}$-gain $\leq \mathbf{0 , 7 0}$ & Sedang \\
$\mathbf{N}-$ Gain $<\mathbf{0 , 3 0}$ & Rendah \\
\hline
\end{tabular}

Sumber : (Archambault, 2008)

Pada Tabel 3. Dapat dinyatakan jika skor N-Gain kurang dari 0,30 maka dapat kriterianya rendah, jika nilai gain berada diantara 0,30 dan 0,70 maka dapat dikategorikan sedang, yang terakhir nilai gain dikategorikan tinggi apabila nilai gain 0,70 atau lebih.

\section{HASIL DAN PEMBAHASAN}

Dari data yang telah dianalisis kemudian diperoleh hasil nilai N-Gain dari 6 sampel jurnal ilmiah yang kemudian dibagi berdasarkan jenjang pendidikan, materi pembelajaran, dan bahan ajar yang digunakan dalam penelitian tersebut, dan hasilnya dapat dijelaskan sebagai berikut:

Berdasarkan jenjang pendidikan 
Sikap Ilmiah

Keefektifan penggunaan model PBL terhadap Sikap Ilmiah peserta didik dapat dilihat pada Gambar 1.

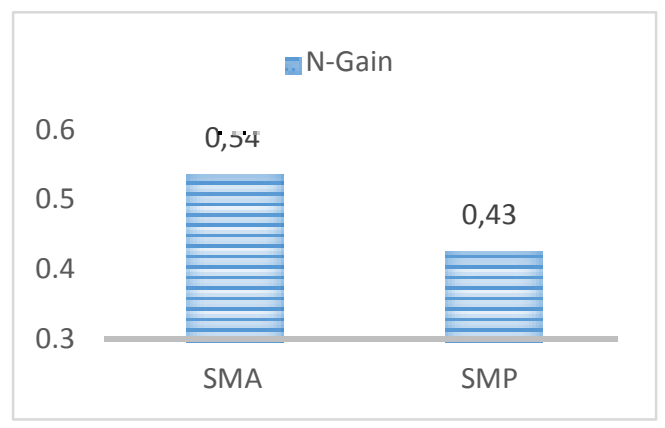

Gambar 1. Nilai Gain pada Jenjang Pendidikan untuk Sikap Ilmiah

Dari grafik hasil meta-analisis diatas menunjukkan bahwasannya penggunaan model Problem Based Learning pada jenjang SMA diperoleh nilai gain sebesar 0,54 dengan kategori sedang dan pada jenjang SMP diperoleh nilai gain 0,43 juga pada kategori sedang. Kemudian dari kedua data diatas dapat diambil kesimpulan bahwa hasil nialai gain keduanya sama-sama pada kategori sedang sehingga penggunaan model PBL terhadap mengembangkan sikap ilmiah peserta didik akan diperoleh hasil yang sama-sama efektif jika diterapkan pada jenjang SMA maupun SMP.

Kemampuan Berpikir Kritis

Keefektifan model PBL terhadap kemampuan berpikir kritis peserta didik dapat dilihat pada Gambar 2.

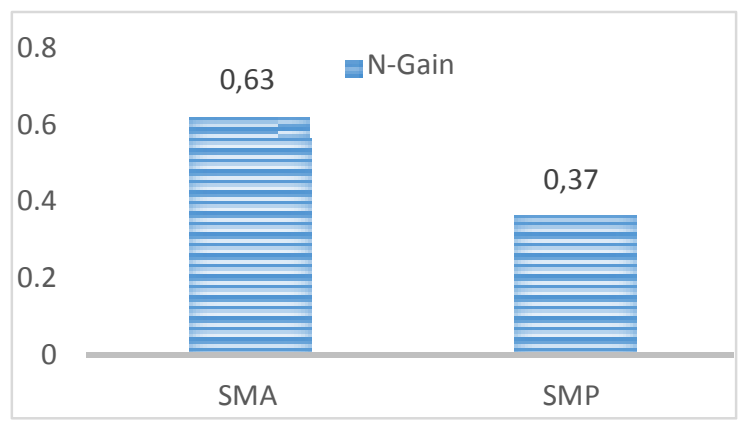

Gambar 2. Nilai pada Jenjang Pendidikan untuk Keterampilan Berpikir Kritis

Dari grafik meta-analisis Gambar 2. diperoleh nilai gain pada penggunaan model PBL pada jenjang SMA adalah 0,63 dengan kategori sedang kemudian pada jenjang SMP diperoleh hasil 0,37 juga pada kategori sedang. Nilai keduanya memiliki selisih 0,26 dan pada jenjang SMA hampir menyentuh kategori tinggi. Jadi kesimpulannya adalah keduanya pada kategori sedang, sehingga model PBL efektif bila digunakan pada jenjang SMA dan SMP terhadap kemampuan berpikir kritis.

Berdasarkan Materi Pembelajaran

Sikap Ilmiah

Keefektifan penggunaan model PBL terhadap mengembangkan sikap ilmiah peserta didik berdasarkan mata pelajaran dapat dilihat pada Gambar 3.

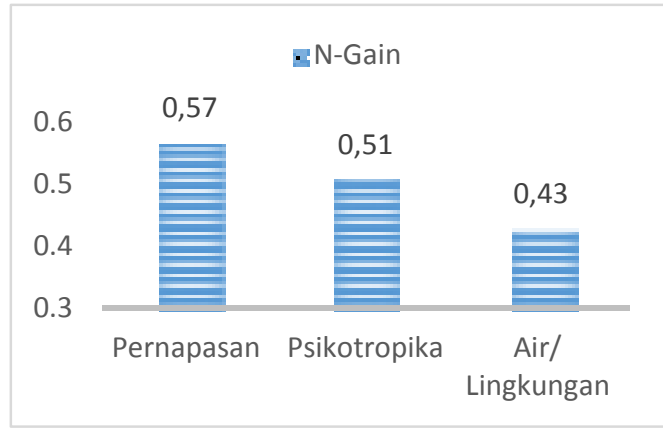

Gambar 3. Nilai materi pembelajaran untuk Sikap Ilmiah 
Dari data yang diperoleh Gambar 3 tersebut bahwa gain dari masing-masing materi pembelajaran adalah yang pertama materi tentang sistem pernapasan manusia dengan gain sebesar 0,57 selanjutnya adalah materi pembeljaran tentang psikotropika dengan gain 0,51 dan terakhit materi air dan lingkungan memperoleh nilai gain sebesar 0,43 . Jika di urutkan ketiga materi pembelajaran diatas mulai dari yang memiliki nilai gain paling rendah ke tinggi adalah materi pernapasan manusia, psikotropika, kemudian yang terakhir air dan lingkungan. Ketiganya memiliki kategori yang sama yakni pada kategori sedang. Jadi dapat disimpulkan bahwasannya model PBL efektif jika diterapkan pada ketiga materi pembelajaran diatas.

\section{Kemampuan Berpikir Kritis}

Keefektifan penggunaan model PBL terhadap kemampuan berpikir kritis peserta didik berdasr mata pelajaran dapat dilihat pada Gambar 4. Dibawah ini

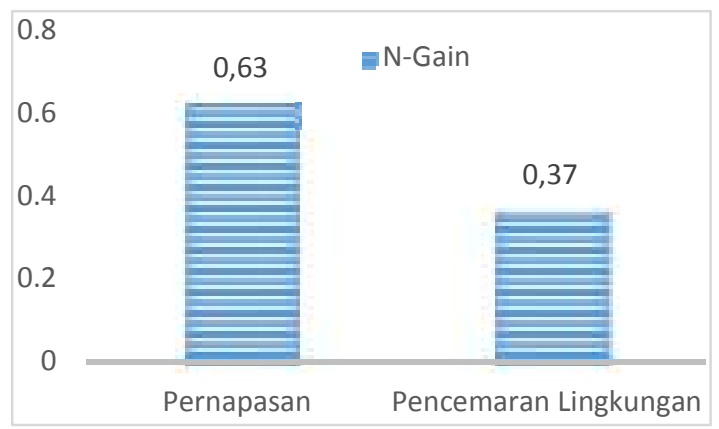

Gambar 4. Nilai materi pembelajaran untuk kemampuan berpikir kritis

Dari grafik nilai gain diatas berdasarkan materi pembelajaran diperoleh hasil materi pernapasan manusia sebesar 0,63 termasuk kategori sedang dan pada materi pembelajaran pencemaran lingkungan diperoleh nilai gain sebesar 0,37 juga termasuk dalam kategori sedang. Dapat disimpulkan bahwa sama-sama efektif untuk menerapkan materi pembelajaran dengan kedua tema diatas.

Berdasarkan Bahan Ajar yang Digunakan

Sikap Ilmiah

Keefektifan penggunaan model PBL terhadap sikap ilmiah peserta didik berdasarkan bahan ajar dapat diperhatikan pada Gambar 5.

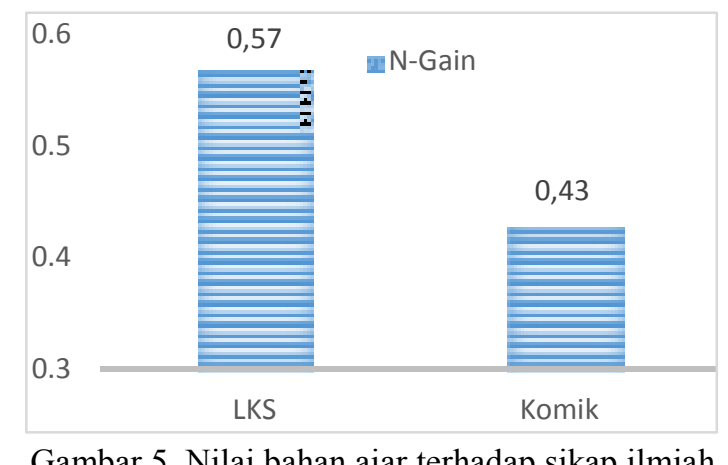

Berdasar gambar 5. Diatas nilai gain bahan ajar untuk iskap ilmiah ada dua, nilai yang pertama dari bahan ajar menggunakan komik sebesar 0,43 sedangkan bahan ajar menggunakan LKS (Lembar Kerja Siswa) diperoleh nilai gain sebesar 0,57. Maka keduanya dapat dikategorikan kedalam klasifikasi sedang. Dapat ditarik kesimpulan bahwasannya kedua bahan ajar diatas efektif jika diterapkan dalam proses pembelajaran.

Keterampilan Berpikir Kritis

Keefektifan penggunaan model PBL terhadap keterampilan berpikir kritis dapat diperhatikan pada Gambar 6. 


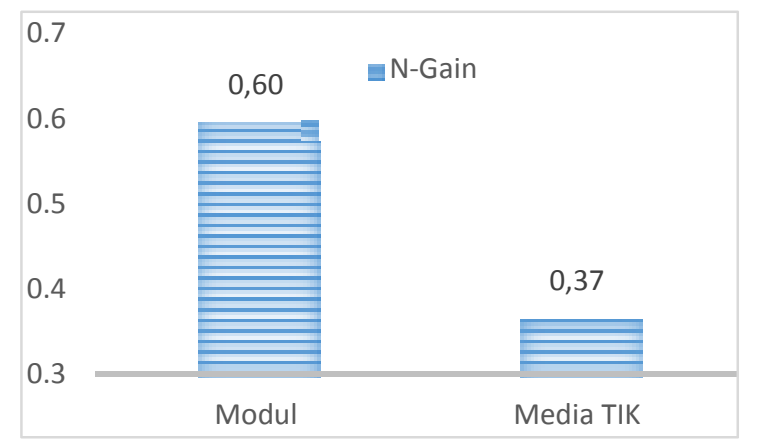

Gambar 6. Nilai bahan ajar terhadap kemampuan berpikir kritis

Dilihat dari Gambar 6. Diperoleh nilai gain pada masing-masing variabel bahan ajar adalah modul memeperoleh nilai sebesar 0,60 sedangkan penggunaan media TIK (Tekhnologi Informasi \& Komunikasi) diperoleh hasil sebesar 0,37 dan keduanya sama-sama memiliki kategori sedang. Sehingga dapat disimpulkan bahwa dengan menggunakan bahan ajar berupa modul dan media TIK untuk meningkatkan keterampilan berpikir kritis, efektif diterapkan ke peserta didik.

\section{PEMBAHASAN}

Secara keseluruhan analisis yang telah dilakukan pada 7 jurnal ilmiah maka diperoleh hasil bahwasannya model pembelajaran berbasis masalah memberikan efektivitas yang cukup baik. Hal ini juga diketahui dari beberapa penelitian sebelumnya yang menyebutkan bahwasannya terdapat perbedaan kemampuan berpikir kritis secara signifikan asntara peserta didik yang mengikuti pembelajaran melalui pendekatan pembeljaran berbasis masalah dengan pembelajaran konvensional ( Siti Maryam, 2014). Hal tersebut juga diungkapkan (Darmawan, 2010) dalam penelitiannya bahwa dengan pola pembelajaran berbasis masalah keterampilan siswa dalam pembelajaran mengalami peningkatan yang berarti setelah proses belajar mengajar diterapkan pembelajaran berbasis masalah siswa menjadi lebih kritis baik itu dalam mengeluarkan pendapat, bertanya, mengidentifikasi masalah dan memberikan solusi pada permasalahan yang ada di lingkungan sekitar peserta didik. Selain terbukti efektif meningkatkan kemampuan berpikir kritis, pembelajaran berbasis masala juga efektif dalam melatih serta mengembangkan sikap ilmiah, seperti yang disimpulkan ( Surya, 2015) dalam penelitiannya pembelajaran berbasis masalah sikap ilmiah siswa kelas eksperimen meningkat signifikan pada dua indikator dibanding pada kelas kontrol.

Meskipun seluruh hasil dari variabel dalam penelitian ini menunjukkan kategori sedang tetapi beberapa memiliki nilai lebih dominan dibandingkan yang lainnya. Maka dari itu, garis besar penelitian hasil meta-analisis tentang efektivitas model Problem Based Learning terhadap kemampuan berpikir kritis dan sikap ilmiah adalah yang pertama, berdasarkan jenjang pendidikan, setelah dilakukan analisis diperoleh hasil bahwa model PBL efektif diterapkan pada jenjang pendidikan SMA maupun SMP, untuk menigkatkan kemampuan berpikir kritis dan sikap ilmiah. (Siti Maryam, 2014) dalam temuannya mengungkapkan siswa memiliki kemampuan dalam berargumentasi untuk menjelaskan permasalahan dengan bahasa dan jalan pikiran yang logis.

Selanjutnya meta-analisis berdasarkan materi pembelajaran menunjukkkan hasil bahwa efektif menerapkan model PBL untuk meningkatkan kemampuan berpikir kritis dan sikap ilmiah peserta didik. Berdasarkan data yang telah dianalisis ditemukan bahwa materi sistem pernapasan manusia lebih efektif jika dibandingkan dengan materi yang lain kemudian juga ditemukan bahwa dari ke 7 jurnal yang digunakan untuk sampel, 4 jurnal diantaranya menggunakan materi pembelajaran yang sama yakni sistem pernapasan manusia. Dalam materi sistem pernapasan manusia, didalamnya memuat tentang konsep-konsep yang menjelaskan suatu proses permasalahan biologi yang memang dekat dengan kehidupan sehari-hari, contohnya adalah kegiatan bernafas yang dilakukan seluruh manusia, sehingga konsep serta urutan proses- proses biologi yang termuat dalam materi pernapasan dapat dengan cepat diterima oleh peserta didik.

Berikutnya hasil meta-analisis pada penggunaan bahan ajar dalam proses pembelajran, diperoleh hasil bahwa modul serta LKS lebih efektif digunakan dalam proses pembelajaran daripada bahan ajar yang lain. Penggunaan modul dalam proses pembelajaran bisa efektif diarenakan beberapa faktor, hal ini dikarenakan modul memiliki beberapa keunggulan disbanding pembelajaran yang dilakukan oleh guru secara langsung yaitu sebagai bahan ajar yang pelengkap yang di dalamnya terdapat ilustrasi dan foto yang lebih komunikatif (Andi Prastowo, 2014).Sedangkan LKS efektif digunakan karena LKS memuat tentang materi yang lebih ringkas dan jelas kemudian cenderung lebih banyak lembar tugas, di LKS juga biasanya terdapat panduan praktikum sehingga lebih memudahkan peserta didik menentukan konsep sikap ilmiah. 


\section{KESIMPULAN}

Berdasarkan hasil dari pembahasan meta-analisis yang telah dijabarkan adalah penggunaan model PBL dengan beberapa simpulan sebagai berikut.

1. Berdasarkan jenjang pendidikan baik SMA maupun SMP keduanya efektif untuk meningkatkan kemampuan berpikir kritis dan sikap ilmiah peserta didik;

2. Berdasarkan materi pembelajaran, seluruh materi efektif digunakan dengan model PBL. Namun jika dilihat dari selisih data, materi tentang sistem pernapsan manusia lebih efektif daripada materi lainnya untuk meningkatkan kemampuan berpikir kritis dan sikap ilmiah peserta didik;

3. Berdasarkan bahan ajar yang digunakan, seluruh bahan ajar efektif diterapkan menggunakan model PBL untuk kemampuan berpikir kritis dan sikap ilmiah. Tetapi jika dilihat dari selisih data, maka model PBL akan lebih efektif jika menggunakan bahan ajar Modul untuk meningkatkan kemampuan berpikir kritis.

\section{UCAPAN TERIMAKASIH}

Dengan terselesaikannya jurnal ilmiah ini, Penulis mengucapkan terimakasih yang pertama kepada, Allaah S.W.T karena atas karunianya sehingga penulis dapat menyelesaikan penelitian, yang kedua kepada dosen pembimbing BapakNanang Purwanto, M.Pd yang telah dengan sabar meluangkan waktu membantu merampungkan jurnal ilmiah ini. Serta kepada kedua orang tua dan rekan-rekan yang bersedia menjadi sumber penyemangat.

\section{DAFTAR PUSTAKA}

Archambault, J. 2008. The Effect of Developing Kinematics Concepts Graphically Prior to Introducing Algebraic Problem Solving Techniques. Action Research Required for the Master of Natural Science Degree with Concentration in Physics; Arizona State University.

Aryanti, Firti (2017). Penerapan Problem Based Learning (PBL) berbantuan Teknologi Informasi dan Komunikasi untuk Meningkatkan Kemampuan Berpikir Kritis Siswa Pada Konsep Pencemaran Lingkungan. Jurnal BIOSFER, 2 (1) 14-20.

Chiapetta, L. E., \& Koballa, R. T. (2010). Science Instruction In The Middle And Secondary schools developing fundamental knowledge and skills. New York :Pearson Education, Inc.

Darmawan. (2010). Penggunaan Pembelajaran Berbasis Masalah Dalam Meningkatkan Kemampuan Berpikir Kritis Siswa Pada Pembelajaran IPS di MI Darrusaadah Padeglang. Jurnal Penelitian Pendidikan11(2): Oktober 2010.

Kemdikbud. (2013). Kurikulum 2013. Jakarta: Kemendikbud.

Kurniawati, annisa, Festiyed (2019). Meta-Analisis Efektivitas Model Inkuiri Terbimbing Terhadap Keterampilan Proses Sains Dan Kemampuan Berpikir Kritis Peserta Didik. Pillar of Physics Education Journal. 12 (4) 849-856.

Lestari, Devy Indah, Anti Kolonial (2016). Pengembangan Media Komik IPA Model PBL untuk Meningkatkan Kemampuan Berpikir Analitis dan Sikap Ilmiah. Jurnla Inovasi Pendidikan IPA, 2 (2) 145-155.

Made, W. (2009). Strategi Pembelajaran Inovatif Kontemporer, Jakarta: Bumi Aksara.

Maryam, Siti Fadhilah Palestina, dkk (2014). Penerapan Pendakatan Pembelajaran Berbasis Masalah Terhadap Peningkatan Kemampuan Berpikir Kritis Pada Konsep Sistema Pernapasan Manusia. Jurnal Biotik. 2 (1) $70-76$.

Nursiti, N., \& Barat, W. L. J. (2013). Keterampilan Berpikir Kritis (Critical Thinking Skill) dalam Pembelajaran Ilmu Pengetahuan Sosial. Widyaiswara LPMP Jawa Barat.

Prastowo, Andi. (2014). Pengembangan bahan ajar tematik tinjauan teoritis dan praktik. Jakarta:Kencana Prenadamedia Group.

Purwaningsih, Duri Dyah. (2007). Pengaruh Sikap Ilmiah Terhadap Hasil Belajar Materi Bangun Ruang Siswa SMPN 16 Semarang kelas VIII. SkripsiUniversitas Negeri Semarang. 
Rosdiana, Yulia (2019). Pengaruh Model Pembelajaran Problem Based Learning (Pbl) Terhadap Sikap Ilmiah Dan Hasil Belajar Peserta Didik Pada Sub Materi Psikotropika. Jurnal BIOSFER, 4 (1) 25-32.

Selviani, ike (2019). Pengembangan Modul Biologi Problem Based Learning Untuk Meningkatkan Kemampuan Berpikir Kritis Peserta Didik SMA. IJIS Edu :Indonesian J. Integr. Sci. Education, 1 (2) 147-154.

Setiawan, D. (2007). Pengembangan Bahan ajar, jakarta, Universitas Terbuka.

Sumarmi. (2012). Model-model Pembelajaran Geografi. Aditya Media.

Surya, Erdi (2015). Penerapan Pembelajaran Berbasis Masalah (Pbl) Untuk Meningkatkan Kemampuan Sikap Ilmiah Siswa Pada Konsep Sistem Pernapasan Manusia Di Sma Negeri 11 Banda Aceh. Jurnal Biology Education, 4 (1).

Surya, Erdi Khairil, dkk (2014). Penerapan Pembelajaran Berbasis Masalah (Pbl) Untuk Meningkatkan Kemampuan Berpikir Kritis Siswa Pada Konsep Sistem Pernapasan Manusia Di Sma Negeri 11 Banda Aceh. Jurnal EduBio Tropika, 2 (1) 135-145 